\title{
Angka Kejadian Depresi pada Pasien yang Menjalani Hemodialisis Menggunakan Metode Pengukuran Geriatric Depression Scale
}

\section{Depression Evaluation Numbers in Patients Hemodialysis Using Geriatric Depression Scale Measurement Methods}

\author{
Monica Octafiani ${ }^{1}$, Linda Armelia ${ }^{2}$ \\ ${ }^{1}$ Student Faculty of Medicine, YARSI University, Jakarta \\ 2Lecture Faculty of Medicine, YARSI University, Jakarta \\ Jalan Letjen. Suprapto, Cempaka Putih, Jakarta 10510 \\ Telephone (021) 4206674, 4206675, 4206676 \\ Corresponding author: linda.armelia@yarsi.ac.id
}

\begin{abstract}
Abstrak
Latar Belakang: Penyakit ginjal kronik mengakibatkan penurunan fungsi ginjal progresif dan irreversible sehingga memerlukan terapi pengganti ginjal berupa dialisis atau transplantasi ginjal. Hemodialisis merupakan terapi pengganti ginjal bertujuan membuang limbah metabolik dan kelebihan cairan tubuh melalui darah. Keadaan ini dapat mengganggu psikis pasien berupa depresi. Tujuan: Penelitian ini bertujuan untuk mengetahui angka kejadian depresi pada pasien geriatric yang menjalani hemodialisis dengan menggunakan metode pengukuran geriatric depression scale. Metode: Penelitian ini dilakukan secara deskriptif. Populasi dalam penelitian ini adalah pasien penyakit ginjal kronik yang sedang menjalani hemodialisis di RS Anna Medika Bekasi dari tanggal 20-29 Agustus 2018. Analisis menggunakan Chi-Square. Hasil: Ada 51 pasien yang memenuhi kriteria inklusi dengan 33 (64,7\%) laki-laki dan sisanya perempuan. Pengukuran tingkat depresi sebagai berikut 25 (49\%) tidak depresi; $20(39.2 \%)$ depresi ringan; $5(9.8 \%)$ depresi sedang dan 1 (2\%) depresi berat. Kejadian depresi pada periode HD <12 bulan sebanyaj 24 (47\%): 11 (45.7\%) normal; 10 (41.7\%) depresi ringan; $2(8.4 \%)$ depresi sedang dan 1 (4.2\%) depresi berat. Pada HD 12-24 bulan sebanyaj 15 (29.4\%): 7 (46.6\%) normal; 6 (40\%) depresi ringan; 2 (13.4\%) depresi sedang dan tidak ada depresi berat. Pada HD 25-36 bulan sebanyak 5 (25.5\%): 4(80\%) normal dan $1(20 \%)$ depresi ringan. Sementara pada HD $>36$ bulan sebanyak 7 (35.7\%): 3 (42.8\%) normal; 3 (42.8\%) depresi ringan dan 1 (14.2\%) depresi sedang". Tidak adanya hubungan antara ketaatan agama dengan angka kejadian depresi pada pasien PGK yang menjalani HD ( $p>0,05)$. Simpulan: Angka kejadian depresi terbanyak terjadi ketika pasien yang menjalani hemodialisis kurang dari 12 bulan dan untuk pasien yang sudah menjalani hemodialisis lebih dari 12 bulan sudah dapat beradaptasi dan bergantung pada dukungan keluarga. Saran: Diperlukan perhatian dan dukungan keluarga pada pasien penyakit ginjal kronik sebagai dukungan moral yang sangat penting dalam mencegah depresi pada pasien disamping kekuatan amal ibadah pasien juga.
\end{abstract}

Kata Kunci: Hemodialisis, Penyakit Ginjal Kronis, Geriatric depression scale 


\section{Abstract}

Background: Chronic kidney disease is a decrease in kidney function that requires a constant renal replacement therapy. Hemodialysis is a renal replacement therapy that aims to removing metabolic waste and excess body fluids through the blood. This condition can disturb the patient's psychic in the form of depression. Objective: This study aimed to determine the incidence of depression in geriatric patients undergoing hemodialysis using the method of geriatric depression scale measurement. Method: This study was conducted with a descriptively. The population in this study were chronic kidney disease patients who were undergoing hemodialysis at Anna Medika Hospital Bekasi from August 2029, 2018. Analysis data using Chi-Square. Results: There were 51 patients who met the inclusion criteria with 33 (64.7\%) men and the remaining women. Measurements of depression levels were 25 (49\%) not depressed, 20 (39.2\%) mild depression, 5 (9.8\%) moderate depression and 1 (2\%) major depression. The association of depression rates with duration of $H D$ was $H D<12$ months 24 (47\%): 11 (45.7\%) normal, 10 (41.7\%) mild depression, 2 (8.4\%) moderate depression and 1 (4.2\%) major depression. HD 12-24 months 15 (29.4\%): 7 (46.6\%) normal, 6 (40\%) mild depression, 2 (13.4\%) moderate depression and no major depression. HD 25-36 months 5 (25.5\%): 4 (80\%) normal and 1 (20\%) mild depression. For HD> 36 months 7 (35.7\%): 3 (42.8\%) normal, 3 (42.8\%) mild depression and $1(14.2 \%)$ moderate depression. There is no relationship between religious observance and the incidence of depression in CKD patients undergoing HD ( $p>0.05)$. Conclusion: The highest incidence of depression occurs when patients undergoing hemodialysis are less than 12 months and for patients who have undergone hemodialysis for more than 12 months have been able to adapt and depend on family support. Suggestion: Family attention and support is needed for patients with chronic kidney diseases as moral support that in very important in preventing depression in patients as well as the power of patients worship.

Key words: $\quad H e m o d i a l y s i s$, Chronic Kidney Dieseases, Geriatric depression scale

\section{Pendahuluan}

Penyakit ginjal kronik (PGK) adalah kerusakan ginjal atau penurunan laju filtrasi glomerulus (LFG) $<60 \mathrm{ml}$ menit/1,73m² untuk jangka waktu $\geq 3$ bulan (Roesli, Rully, 2006). PGK mengakibatkan penurunan fungsi ginjal progresif dan irreversible sehingga memerlukan terapi pengganti ginjal (TPG), berupa dialisis atau transplantasi ginjal. Penyakit ginjal kronis merupakan masalah kesehatan masyarakat global dengan prevalensi dan insiden gagal ginjal yang meningkat, prognosis buruk dan biaya tinggi (Kementerian Kesehatan RI. 2017). World
Health Organization (WHO) memperkirakan peningkatan pasien PGK di Indonesia pada tahun 1995-2025 sebesar 41,4\% dan menurut data Persatuan Nefrologi Indonesia (Pernefri) diperkirakan terdapat 70.000 pasien penyakit ginjal di Indonesia, dimana angka ini akan terus meningkat sekitar $10 \%$ setiap tahunnya (Suwitra, 2009.

Penyakit ginjal kronik dapat digolongkan sebagai pemicu (stressor) yang bisa menimbulkan stres pada seseorang. Pasien yang menjalani hemodialysis (HD) umumnya mengalami stress (Soehardjono, 2006). Pasien 
ini beranggapan bahwa mereka akan tergantung pada mesin dialisis. Keadaan ini sering menimbulkan pemikiran dalam diri pasien bahwa nyawanya terancam, harapan hidup berkurang, ketakutan bahwa usianya tidak lama lagi sehingga permasalahan ini juga menimbulkan konflik dalam keluarga (Giordano et al., 2007).

\section{Geriatric Depression Scale (GDS)}

adalah kuisioner yang dirancang khusus untuk medeteksi depresi pada subjek usia lanjut (geriatric). GDS memiliki sensitivitas $85 \%$ dan spesifisitas $68 \%$ dengan cara wawancara kejiwaan terstruktur terhadap diagnosis berdasarkan wawancara kejiwaan yang terstruktur (Katona et al., 1994).

Ajaran Islam memotivasi terhadap perkembangan ilmu pengetahuan dan teknologi yang dapat memberikan manfaat dan kemudahan termasuk diantaranya HD yang digunakan untuk terapi PGK. Beberapa penelitian untuk mengukur angka kejadian depresi dengan menggunakan metode Geriatric Depression Scale (GDS) dapat mengukur tingkat depresi.

\section{Bahan dan Metoda Penelitian}

Jenis penelitian dilakukan secara deskriptif (descriptive cross sectional study) yang bertujuan untuk mengetahui angka kejadian depresi pada pasien penyakit ginjal kronis (PGK) lanjut usia (geriatric) yang menjalani hemodialisis (HD) di RS Anna Medika Bekasi dari tannggal 20-29 Agustus 2018. Pengambilan subyek berupa identifikasi pasien dengan cara consecutive sampling yaitu semua subyek yang datang dan memenuhi kriteria inklusi seperti bersedia mengikuti penelitian, usia lebih dari sama dengan 60 tahun, kondisi stabil dan dapat berkomunikasi dengan baik serta tidak memiliki riwayat gangguan psikologi.

\section{Hasil Penelitian}

Ada 156 pasien HD di RS Anna Medika, tetapi hanya 51 pasien yang memenuhi kriteria inklusi ydengan hasil seperti pada table 1.

Distribusi sampel berdasarkan jenis kelamin $33(64,7 \%)$ laki-laki dan sisanya perempuan.

Tabel 1. Karakteristik Demografi

\begin{tabular}{cc}
\hline Karakteristik & $\begin{array}{c}\text { Jumlah (n) dan } \\
\text { Persentase (\%) }\end{array}$ \\
\hline Jenis kelamin & 33 / 64.7 \\
Laki-laki & $18 / 35.3$ \\
Perempuan & \\
Lama HD (bulan) & $24 / 34.3$ \\
$<12$ & $15 / 21.4$ \\
$12-24$ & $5 / 7.1$ \\
$25-36$ & $7 / 10.0$ \\
$>36$ & $20 / 39.2$ \\
Penyebab HD & $20 / 39.2$ \\
DM & $3 / 5.9$ \\
Hipertensi & $5 / 9.8$ \\
Asam Urat & $1 / 2.0$ \\
Batu Ginjal & $2 / 3.9$ \\
Obat-obatan & \\
Lainnya & $50 / 98$ \\
Ketaatan Beragama & $1 / 2$ \\
Sangat Taat & $0 / 0$ \\
Taat & $0 / 0$ \\
Cukup Taat & \\
Kurang Taat &
\end{tabular}

Berdasarkan kelompok lama menjalani HD didapatkan hasil sebanyak 24 (34,3\%) HD $<12$ bulan, 15 (21,4\%) HD 12-24 bulan, 5 (7,1\%) HD 25-36 bulan dan 7 (10\%) HD >36 bulan.

Berdasarkan penyebab pasien harus menjalani HD, didapatkan hasil sebanyak 20 $(39,2 \%)$ diabetes militus (DM), 20 (39,2\%) hipertensi, $3(5,9 \%)$ asam urat, $5(9,8 \%)$ batu ginjal dan 1 (2,0\%) obat-obatan dan 2 (3,9\%) karena minuman keras.

Tingkat stress pada pasien yang menjalani HD bisa dipengaruhi oleh ketaatan beragamanya. Pada penelitian ini evaluasi terhadap ketaatan beragama didapatkan 50 $(98 \%)$ sangat taat dan $1(2 \%)$ taat terhadap agama, tidak didapatkan pasien yang cukup taat $(0 \%)$ ataupun kurang taat $(0 \%)$. 
Tabel 2. Angka Kejadian Depresi Menggunakan Metode Pengukuran Geriatric Depression Scale

\begin{tabular}{lc}
\hline Tingkat Depresi & $\begin{array}{c}\text { Jumlah }(\mathrm{n}) \text { dan persentase } \\
(\%)\end{array}$ \\
\hline Normal & $25(49)$ \\
Ringan & $20(39.2)$ \\
Sedang & $5(9.8)$ \\
Berat & $1(2)$ \\
\hline
\end{tabular}

Berdasarkan tabel diatas didapatkan sebanyak 25 (49\%) tidak depresi, 20 (39.2\%) depresi ringan, 5 (9.8\%) depresi sedang dan 1 (2\%) depresi berat.

Data yang telah dikumpulkan kemudian dianalisis dengan rumus Chi Square untuk mengetahui distribusi kejadian depresi berdasarkan jenis kelamin, lama hemodialisis dan tingkat depresi (table 3).

Berdasarkan tabel 3 didapatkan angka kejadian depresi pada laki-laki sebanyak 34 (66,7\%), dimana sebanyak 18 (53\%) normal, 12 (35.3\%) depresi ringan, 3 (8.8\%) depresi sedang dan 1 $(2.9 \%)$ depresi berat. Sedangkan pada perempuan didapatkan $17(33,3 \%)$ dengan perincian 7 (41.2\%) normal, 8 (47\%) depresi ringan, 2 (11.8\%) depresi sedang dan tidak ada yang depresi berat. Hubungan angka kejadian depresi dengan lama menjalani HD didapatkan hasil: yang menjalani HD <12 bulan sebanyak 24 (47\%) dengan perincian 11 (45.7\%) normal, 10 $(41.7 \%)$ depresi ringan, 2 (8.4\%) depresi sedang dan 1 (4.2\%) depresi berat. Untuk yang sudah menjalani HD 12-24 bulan sebanyak 15 (29.4\%) dengan rincian 7 (46.6\%) normal, 6 (40\%) depresi ringan, 2 (13.4\%) depresi sedang dan tidak ada depresi berat. Untuk waktu HD 25-36 bulan sebanyak 5 (25.5\%) dengan perincian $4(80 \%)$ normal dan 1 (20\%) depresi ringan sedang untuk depresi sedang dan berat tidak ada yang mengalami. Untuk waktu HD >36 bulan sebanyak 7 (35.7\%) dengan rincaian 3 (42.8\%) normal, 3 (42.8\%) depresi ringan dan 1 (14.2\%) depresi sedang serta tidak ada yang depresi berat.

Berdasarkan hubungan tingkat depresi pada pasien HD dengan kepatuhan terhadap agama. didapatkan tidak adanya hubungan antara ketaatan agama dengan angka kejadian depresi pada pasien PGK yang menjalani HD $(p>0,05)$ (tabel 4).

Tabel 3. Angka kejadian depresi berdasarkan jenis kelamin dan lama HD

\begin{tabular}{|c|c|c|c|c|c|}
\hline \multirow[t]{2}{*}{ Angka kejadian depresi } & \multicolumn{4}{|c|}{ Tingkat Depresi $(\mathrm{n})$ dan Persentase (\%) } & \multirow{2}{*}{$\begin{array}{l}\text { Jumlah (n) dan } \\
\text { Persentase (\%) }\end{array}$} \\
\hline & Normal & Ringan & Sedang & Berat & \\
\hline \multicolumn{6}{|l|}{ Jenis kelamin } \\
\hline Laki-laki & $18(53)$ & $12(35.3)$ & $3(8.8)$ & $1(2.9)$ & $34(66.7)$ \\
\hline Perempuan & $7(41.2)$ & $8(47)$ & $11.8)$ & 0 & $17(33.3)$ \\
\hline \multicolumn{6}{|l|}{ Lama HD (bulan) } \\
\hline$<12$ & $11(45.7)$ & $10(41.7)$ & $2(8.4)$ & $1(4.2)$ & $24(47)$ \\
\hline $12-24$ & $7(46.6)$ & $6(40)$ & $2(13.4)$ & 0 & $15(29.4)$ \\
\hline $25-36$ & $4(80)$ & $1(20)$ & 0 & 0 & $5(25.5)$ \\
\hline$>36$ & $3(42.8)$ & $3(42.8)$ & $1(14.2)$ & 0 & $7(35.7)$ \\
\hline
\end{tabular}

Tabel 4. Angka kejadian depresi dan ketaatan beragama

\begin{tabular}{cccccc}
\hline Tingkat Ketaatan & \multicolumn{4}{c}{ Tingkat Depresi (orang) } & $\begin{array}{c}\text { Jumlah }(\mathrm{n}) \text { dan } \\
\text { Persentase }(\%)\end{array}$ \\
\cline { 2 - 5 } Beragama & Normal & Ringan & Sedang & Berat & $50(98)$ \\
Sangat Taat & 25 & 19 & 5 & 1 & $1(2)$ \\
Taat & 0 & 1 & 0 & 0 & 0 \\
Cukup Taat & 0 & 0 & 0 & 0 & 0 \\
Kurang Taat & 0 & 0 & 0 & 0 & $51(100)$ \\
\hline Jumlah & 25 & 20 & 5 & 1 & \\
\hline
\end{tabular}




\section{Diskusi}

Berdasarkan hasil penelitian pasien PGK yang menjalani HD di RS Anna Medika Bekasi ada 156 orang, tetapi hanya $51(32.7 \%)$ yang memenuhi kriteria inklusi penelitian ini. Didapatkan hasil 25 (49\%) normal, 20 (39.2) depresi ringan, 5 (9,8\%) depresi sedang dan 1 (2\%) depresi berat. Pasien PGK yang menjalani HD di RS lebih kurang sebanding antara yang normal $25(49 \%)$ dan yang mengalami depresi 26 $(51 \%)$. Hal ini terjadi karena sebagian pasien sudah meninggalkan banyak kegiatan dan minat atau kesenangan, berkurangnya kegiatan yang dilakukan, merasa kosong dan bosan, serta terkadang merasa sedih dan penurunan daya ingat.

Depresi merupakan sesuatu pengalaman yang menyakitkan yaitu suatu perasaan tidak ada harapan hidup lagi (Lubis \& Lumongga, 2009). Tingginya kejadian depresi pada pasien PGK yang menjalani HD disebabkan oleh berbagai faktor yang berhubungan dengan kehidupan sosial, psikologis dan mekanisme biologis. Depresi terjadi bisa karena adanya pembatasan supaya penyakit tidak makin memperparah pasien seperti pembatasan asupan cairan, pantangan makanan tertentu, disertai keluhan berupa mual, lemah, sesak nafas dan komplikasi lainnya yang membuat pasien tidak dapat bekerja seperti sebelum sakit serta ketakutan terhadap masa depan. Terapi HD secara rutin dan perubahan status kesehatan akan mempengaruhi terhadap rasa putus asa. Sehingga akan mudah menimbulkan depresi (Rustina, 2012). Sebanyak $20(39,2 \%)$ pasein mengalami depresi ringan dan $5(9,8 \%)$ depresi sedang. Tingkatan depresi ini banyak didapat pada pasien PGK menjalani HD $<12$ bulan. Keadaan ini bisa dikarenakan mereka masih dalam proses adaptasi terhadap terapi HD yang mereka jalani sebanyak $2-3 \times$ per minggu dan mereka harus menerima keadaan walaupun berat bahwa mereka menderita penyakit yang tidak mungkin untuk disembuhkan serta membutuhkan biaya yang besar. Hasil penelitian ini sejalan dengan apa yang disampaikan oleh Terraciano et al., (2013) yang menyatakan bahwa pola depresi pada orang dewasa mengikuti pola "bentuk U", dimana orang dewasa muda lebih berisiko menderita depresi, menurun selama usia pertengahan, dan meningkat kembali di usia lanjut.

Depresi berat didapatkan pada $1(2 \%)$ pasien yang merupakan pasien baru. Hal ini sesuai dengan penelitian yang dilakukan oleh Rustina (2012) yang mendapatkan hasil sama. Keadaan ini bisa karena pasien yang telah lama dengan yang baru menjalani HD, maka seseorang akan lebih adaptif dengan HD. Pasien yang sudah lama HD mungkin sudah dalam fase penerimaan dengan keadaan, sehingga tingkat depresinya lebih rendah dibandingkan pasien baru. Saat pertama kali pasien didiagnosis dengan PGK dan harus menjalani HD selamanya maka akan timbul rasa khawatis dan cemas dalam diri pasien sehingga bisa memicu tingkatan stress berupa depresi pada diri pasien.

Sebanyak $25(49 \%)$ normal karena pasien yang masuk dalam kelompok ini sudah lama menjalani HD dan mereka sudah beradaptasi dengan kegiatan HD yang harus dilakukan untuk menunjang kesehatannya. Selain itu, faktor lain berupa dukungan keluarga merupakan faktor penting yang sangat membantu bagi pasien untuk tetap bertahan dengan status kesehatannya karena pasien merasakan adanya dukungan secara emosional berupa rasa diperhatikan sehingga memberikan rasa menyenangkan bagi dirinya. 
Dukungan keluarga baik moril maupun materi sangat diperlukan bagi pasien yang mengidap penyakit kronis untuk memperbaiki masalah psikis yang dialaminya (Lubis \& Lumongga, 2009).

Penelitian yang dilakukan oleh Siti $\mathrm{A}$ (2017), didapatkan sebagian besar $(57,89 \%)$ pasien usia dewasa tidak mengalami depresi. Hal ini terjadi karena lansia sudah merasa cukup dengan hidup yang sudah dilampauinya dan dukungan dari keluarga untuk selalu tetap berjuang dan semangat dalam menjalani sisa umur.

Kesimpulan penelitian ini adalah angka kejadian depresi pada pasien yang sedang menjalani HD dipengaruhi oleh lamanya waktu pasien menjalani HD, pada pasien baru menjalani HD depresi timbul karena adanya perbedaan aktivitas yang harus dilakukan dari sebelum sakit tetapi lama kelamaan mereka terbiasa dan beradaptasi terhadap penyakit dan pengobatan khususnya HD. Dukungan keluarga sangat membantu dan berpengaruh dalam memperkuat kondisi psikis pasien.

Berdasarkan hasil uji statistik tidak didapat adanya hubungan antara ketaatan agama dengan angka kejadian depresi pada pasien PGK yang menjalani HD ( $p>0,05)$. Hal ini disebabkan karena kuisioner yang ditanyakan hanya dasar saja yang bersifat subyektif, seperti kepercayaan akan adanya Tuhan, melakukan aktifitas ibadah setiap hari, perasaan tenang setelah beribadah, dan melakukan kegiatan keagamaan walau hanya melalui televisi. Sejatinya ketaatan kepada Tuhan dapat diukur dengan intensitas pasien beribadah kepada tuhannya secara terperinci.

\section{Simpulan}

Penelitian ini menyimpulkan bahwa angka kejadian depresi pada pasien PGK geriatri yang menjalani HD dipengaruhi oleh lamanya pasien menjalani HD serta diperlukan dukungan keluarga untuk memperkuat kondisi psikis pasien. Tetapi tidak didapatkan adanya hubungan antara tingkat depresi dengan ketaatan beragama.

\section{Saran}

Hasil penelitian dapat dijadikan sebagai bahan pertimbangan pelayanan keperawatan terutama dalam menangani masalah psikologis khususnya depresi pada pasien PGK yang sedang menjalani HD. Keluarga dan masyarakat diharapkan dapat memberikan perhatian kepada pasien yang sedang menjalani HD karena moral support sangat dibutuhkan untuk kelangsungan hidup pasien. Kepada peneliti lain terkait dengan masih banyak responden yang berdiskusi dengan keluarga dalam pengisian kuisioner maka ditekankan kepada responden untuk tidak berdiskusi agar mendapatkan hasil yang lebih akurat dan untuk alat ukur seperti kuisioner diharapkan memiliki pertanyaan mendetail agar mendapatkan hasil yang signifikan.

\section{Daftar Pustaka}

Giordano et al., 2007. Screening of Depressive Symptoms in Young-Old Hemodialysis Patients: Relationship between Beck Depression Inventory and 15-Item Geriatric Depression Scale. Italy: Nephrons Clinical Practice Scientific Institute of Telese/Campoli.

Jayanti D. 2008. Hubungan Stres dan Mekanisme Koping dengan Dukungan Sosial Keluarga dalam Merawat pasien Gagal Ginjal Kronis di Unit Hemodialisa Rumah Sakit Angkatan 
Darat Gatot Subroto Jakarta Tahun 2008. UPN Veteran Jakarta

Katona et al., 1994. Screening, detection and management of depression in elderly primary care attenders. I: The acceptability and performance of the 15 item Geriatric Depression Scale (GDS15) and the development of short versions. Inggris: Princess Alexandra Hospital, Harlow, Essex 11(3):260-266.

Kementerian Kesehatan RI. 2017. Situasi Penyakit Ginjal Kronik. Jakarta: Pusat Data dan Informaasi Kementerian Kesehatan RI.

Lubis, Namora Lumongga. 2009. Am Depresi:

Tinjauan Psikologis. Jakarta: Kencana Prenada Media Group.

Roesli, Rully MA. 2006. Terapi Pengganti Ginjal Berkesinambungan (CRRT). Jakarta: Buku Ajar IImu Penyakit Dalam Fakultas Kedokteran Universitas Indonesia 1 (4):596-599.

Rustina. 2012. Gambaran Tingkat Depresi pada Pasien Gagal Ginjal Kronik yang Menjalani
Hemodialisis di RSUD Dr. Soedarso Pontianak Tahun 2012. Skripsi Tidak Dipublikasikan. Fakultas Kedokteran Universitas Tanjungpura Pontianak.

Siti A. 2017. Tingkat Depresi dan Kualitas Hidup Pasien Gagal Ginjal Kronik Berdasarkan Tingkatan Usia di RSUD Dr. H. Soewonho Kendal. Kendal: Universitas Muhamadiyah Kendal.

Soehardjono. 2006. Proteinuria Pada Penyakit Ginjal Kronik: Mekanisme dan Pengelolaannya. Jakarta: Divisi Ginjal Hipertensi. Depaertemen Penyakit Dalam FKUI/RS Dr. Ciptomangunkusumo

Suwitra K. 2009. Penyakit Ginjal Kronik. Dalam: Sudoyo AW, Setiyohadi B, Alwi I, Simadibrata M, Setiati S, editor. Buku Ajar IImu Penyakit Dalam Jilid III Edisi V. Jakarta: Interna Publishing.

Terraciano et al., 2013. Clinical Psychology A Modular Course Depression Third Edition. New York: Routlge. 